Available online at $\quad$ http://www.jfas.info

\title{
PRODUCTIVITY AND ECONOMIC EFFICIENCY OF SOYBEAN VARIETIES CULTIVATION UPON APPLICATION OF ORGANIC AND MINERAL FERTILIZERS
}

\author{
E. G. Kotlyarova*, V. G. Gritsin \\ Belgorod State Agricultural University named after V. Gorin, Russia, 308503, Belgorod \\ region, Belgorod district, Maiskiy village, Vavilova Street, 1
}

Published online: 08 August 2017

\begin{abstract}
An objective was set to bring up the production output of soybean in Russia to $7.2 \mathrm{mln}$. tonnes by 2020 . In $20162.9 \mathrm{mln}$. tonnes were produced with the yielding capacity of 15.6 $\mathrm{dt} / \mathrm{ha}$. The Belgorod region ranks second in the all-Russian harvest -502.7 thousand tonnes or $17.4 \%$, with the best yielding index $-24.4 \mathrm{dt} / \mathrm{ha}$. The objective of increasing the soybean output is associated with its yielding capacity enhancement. The varieties of high potential production output were created -3.6 tonnes/ha, for realization of which the nutrient status of plants is important. In this regard the research goal was to study the impact of organic and mineral fertilizers (manure-straw compost (20 tonnes/ha), ammonium nitrate (30 $\mathrm{kg}$ of primary nutrient per ha), Azosol 36 Extra (twice 2 1/ha)) and combinations thereof on the yielding capacity, seed quality and economic efficiency of cultivation of soybean varieties from different maturity groups (early-ripening - Lantsentnaya and mid-season Belgorodskaya 48).Unstable weather conditions giving advantages to either early-ripening or mid-season varieties resulted in the lack of any significant difference of yielding capacity between the varieties under study for three years on average. Fertilizers contributed to growth of the yielding capacity. The maximum yielding capacity of soybean seeds was observedupon application of a complete fertilizer "Compost + Ammonium nitrate +Azosol" - 3.01-3.04 tonnes/ha, which is $18-22 \%$ higher as compared with control.
\end{abstract}

Author Correspondence, e-mail: kotlyarovaeg@mail.ru doi: $\underline{\text { http://dx.doi.org/10.4314/jfas.v9i2s.863 }}$ 
Application of compost fertilizers leveled out differences of varieties of different maturity in terms of protein content in soybean seeds which grew upon saturation of the fertilization status by $3.9-5.3 \%$. As for the fat content the early-ripening variety Lantsentnaya had distinct advantages $-1.4 \%$ higher which contributed to the higher output of oil - by $30 \mathrm{~kg} / \mathrm{ha}$. Soybean can secure the net profit of 21-26 thous. rubles per ha with the profitability level of $70-107 \%$. Compost fertilizers came in a close second to mineral fertilizers securing a profit of 23.5-25.5 thous. rubles per ha.

Keywords: soybean,variety,organic and mineral fertilizers, yielding capacity,seed quality, economic efficiency.

\section{INTRODUCTION}

By virtue of a high (up to $45-48 \%$ ) content of protein and high-quality oil (up to $25 \%$ ) in seeds and multiple use forfeeding, nutritive and technical purposes the soybean is a key agricultural crop. (Perspektivnaya resursosberegayushchaya tekhnologiya.., 2008). At the same time the net cost of soybean proteins in terms of raw materials is 27 times lower as compared with the proteins of animal origin. (Shamray, 2015). It is not fortuitous that soybean seeds production consistently grows throughout the world on an annual basis. It grew by more than $400 \%$ for the last 30 years. In 2015 soybean plantings throughout the world were 118.14 million ha. Total volume of yield was 317.25 million tonnes. USA and Brazil take the lead in beans cultivation on the global market. Almost a third of plantings(33.42 million ha) is in USA (with the highest yielding capacity of 3.21 tonnes/ha). Brazil seeds a bit smaller area (32.1 million ha) with soybean.

Russia ranks $8^{\text {th }}$ in the world on the area of soybean cultivation -1.91 million ha $(1.6 \%$ of the global area). At the same time only $0.82 \%$ of the world output (2.6 million tonnes) falls to the share of Russia. (Tsaritsa poley..., 2015). It is worth noting that at the same time Russia is one of the fastest-growing markets of soybean in the world. In many respects this is due to adoption of the sectorial programme "Development of Production and Processing of Soybean in the Russian Federation for 2015-2020" by the Ministry of Agriculture which was prepared by the Russian Council for Soybean (2014). According to the programme the soybean yield shall grow to 7.2 million tonnes by 2020 .

According to the data of the Ministry of Agriculture of the Russian Federation and Federal State Statistics Service the planting acreage under soybean in Russia in 2016 made 2.2 million ha in the households of all categories, whereas 15 years back (in 2001) it was 416.6 thous. ha. In 20162.9 million tonnes of soybeans were produced with the yielding 
capacity of $15.6 \mathrm{dt} / \mathrm{ha} .15$ years back it amounted to 349.6 thous. tonnes. The Belgorod region is the leading in terms of soybean production output in the country (502.7 thous. tonnes which is $17.4 \%$ of the All-Russia harvest), ranking second after the Amur region (Proizvodstvo soevykh bobov..., 2016), with the best yield index throughout Russia - $24.4 \mathrm{dt} / \mathrm{ha}$ (Kozlova, 2016). According to the data from the Department of the Agro-Industrial Complex and Environment Reproduction of the Government of the Belgorod region the planting acreage under soybean in 2017 makes 211 thous. ha, which is 40 times larger as compared to 2005 (5.2 thous. ha). The share of soybean in the cropping pattern is almost $15 \%$ (V oblasti..., 2017).

Soybean cultivation contributes to the growth of economic viability of plant production. Soybean as a culture is profitable even under the yield of $5 \mathrm{dt} / \mathrm{ha}$ (Soevaya revolyutsiya..., 2008). Soybean profitability depending on the cultivation area and economic climate makes from $40 \%$ (Kolesnikov, 2014) to 274-320\% (Grudkina, Lavrukhina, 2013).

The agronomical value of this bean culture is also great as it is a perfect preceding crop for the corns and improves soil fertility owing to ability to take up atmospheric nitrogen by means of symbiosis with the nodule bacteria - nitrogen fixers.

The significance of soybean in Russia grew due to aggravation of the protein deficiency through the reduction of animal products production for the last 15 years (Fedotov et al., 2011). In the Belgorod region quite the opposite the demand for soybean was aroused by a large-scale development of animal farming. Our region produces $11 \%$ of meat, around $14 \%$ of pork and $18 \%$ of poultry of the All-Russia production. The same reason generates a need for environmentally safe disposal of large amounts of the organic raw staff of animal and poultry production units - over 12 million tonnes( $\mathrm{Ob}$ utverzhdenii territorialnoy skhemy..., 2016).

The value of organic fertilizers in improving soil fertility can hardly be overestimated, and in recent times in the midst of a significant rise in pricesfor mineral fertilizers the former can become an efficient alternative to the latter.

The objective of increasing soybean production is associated in many respects with the growth of its yielding capacity. As of now great success has been achieved in selection. There were created varieties of high potential productivity - 3.6 tonnes/ha (Zelenskaya, 2015), for realization of which the plant nutrient status is important. Fertilizers and varieties having a direct influence on the efficiency of photosynthetic processes are a means of management of 
material and energy flows of solar power and other natural and climatic and anthropogenic resources.

Despite the positive impact of organic fertilizers including poultry manure on the yielding capacity of different agricultural crops established in numerous studies, such studies with regard to soybean are few and highly inconsistent (Titova et. al., 2004;Salvagiotti et al., 2008), especially upon comparison of their efficiency with mineral fertilizers. Some authors give preference to mineral fertilizers (Barsukov, Barsukov, 2005), other - to combination thereof with organic fertilizers (Miyauchi et al., 2012).Also there is no consensus of opinion among researchers regarding the impact of mineral fertilizers on soybean productivity especially with respect to application of nitrogen fertilizers and their rates (Fomin, 2003; Barker andSawyer, 2005, Gan et al., 2003, Schmitt et al., 2001.), since it is considered that the mineral nitrogen inhibits nitrogen fixation by nodule bacteria (Kotlyarova, Laktionov, 2010;Zelenskaya, 2015).

In our studies the varieties of different maturity groups are used: early-ripening variety Lantsentnaya and mid-season variety Belgorodskaya 48. The majority of researchers believe that late-ripening varieties are more productive. At the same time the early-ripening and midseason varieties of soybean due to early maturation enable to gain high-quality seeds which do not require additional drying and to use soybean as a preceding crop for winter cultures. Likhachev A.N. (2002), Musorina L.I. (1987) and other specify that the early-ripening varieties secure the same yielding capacity as late-ripening varieties, i.e. they believe that productivity does not depend on maturing rate of the variety.

The research objective is to discover the optimum combination of fertilizer types and soybean varieties to improvethe efficiency of its cultivation under the conditions of south-west of the Central Black Earth Region.

\section{RESEARCH MATERIALS AND METHODS}

The research area is located in the southern part of the forest-steppe zone of Russia and is characterized by a moderate continental climate with the average annual temperature of $6.2^{\circ}$ $\mathrm{C}$, sum of mean daily temperatures over $10^{\circ} 2750-3050^{\circ}$, and average annual total precipitationof $460-540 \mathrm{~mm}$. The annual hydrothermic coefficient is about 1 and implies that this is the region of unstable humidity. The probability of wet years is $25-40 \%$ whereasthat of semiarid and arid years is $30-50 \%$.

Field studies were conducted in 2014-2016 on the basis of Scientific and Training Innovation Centre "Agrotekhnopark" of theBelgorod State Agricultural University named after V. 
Gorinwith the following crop rotation: soybean - winter wheat - buckwheat - panic grass. The soil on the research plot is typical loamy chernozem. Humus content is $5.1 \%$; pHsalt. $=6.0$; the content of labile phosphorus and potassium (sensu Chirikov) is $125-167$ and $128-133 \mathrm{mg} / \mathrm{kg}$ of soil respectively.

A two-factor experiment includes two levels of factor A (variety): 1. early-ripening Lantsentnaya and 2. mid-season - Belgorodskaya 48 (originator of soybean varieties is the Belgorod State Agricultural University) and eight levels of factorB (fertilizer): 1. Control without application of fertilizers; 2. Compost (henceforward straw-manure compost); 3 . Compost + Ammonium nitrate; 4. Compost + Ammonium nitrate + Azosol; 5. Compost + Azosol; 6. Azosol; 7. Ammonium nitrate + Azosol; 8. Ammonium nitrate. Compost(20 tonnes/ha) was applied in autumn under primary cultivation by a disc harrow BDT-5.4 to a depth of 10-12 cm. Ammonium nitrate at a dose of 30 kgof primary ingredient per ha was applied in spring under preplanting cultivation. Treatment with micro-fertilizer Azosol 36 Extra at a dose of $21 /$ hawas conducted twice on vegetation during phases of the third ternate leaf and budding.

The total area of plots was $37 \mathrm{~m}^{2}$, the accounting area $-25 \mathrm{~m}^{2}$, with three-fold replication, and systematic allocation of plots by a method of arranged repetitions. Crop tending included: the first chemical treatment in a phase of formation of the first ternate leaf by Kvikstep 0.8 1/ha + Harmony $6 \mathrm{~g} / \mathrm{ha}+$ Trend $90+$ Vanteks $60 \mathrm{ml} / \mathrm{ha}$; the second chemical treatment was conducted in a phase of 3-4 ternate leaf by Fusilade Forte 1//ha.

A critical period of an active building up the leafy mass and early flowering of soybean falls to the late June and early July in the Belgorod region. In 2014 and 2015 the hydrothermic conditions of this time of a year were more favourable for the culture - under conditions of a comfortable air temperature for soybean the amount of precipitations was either at the level or a little higher of a multiyear norm. In 2016 hot weatherwith a considerable moisture deficit was observed during this period which affected the yielding capacity especially of the earlyripening variety, the generative organs of which were formed at a high temperature.

\section{RESULTS AND DISCUSSION}

\subsection{Yielding capacity of soybean varieties of different maturity depending on the level of fertilization}

The yielding capacity of agricultural crops is an integral indicator of efficiency of one or another cultivation method including the plant nutrition system. The results of our research 
showed that the yielding capacity of soybean varieties depended on fertilizers and year conditions (Table 1).

In 2014 and 2015 irrespective of the fertilizers applied the early-ripening variety Lantsentnaya positively excelled the mid-season variety Belgorodskaya 48 with regard to the yielding capacity of seeds by a mean of 3-7\%. In 2016 by virtue of the above specified circumstances the situation changed to the contrary. The difference in yielding capacity was 0.57 tonnes/ha or $32 \%$ in favour of Belgorodskaya 48.

It is worth noting that the potential productivity of varieties was realized in 2015 when the average yielding capacity was 3.74-3.87tonnes/ha. The maximum yielding capacity was achieved upon integrated use of compost, ammonium nitrate and foliar dressing and amounted to 4.19 tonnes/hafor the variety Lantsentnaya and 3.90 tonnes/hafor the variety Belgorodskaya 48.The variety Lantsentnayaproved to be more responsive: the increment was $18 \%$ as compared with control, whereas in case of Belgorodskaya 48 it was $11 \%$ only.

Similar situation was observed in 2014. The increment of the early-ripening variety as compared with control was 0.61 tonnes/haor $25 \%$. Moreover, a considerable excess of the yielding capacity of the variety Lantsentnaya as compared with the variety Belgorodskaya 48 during the first two years of research was observed upon application of compost and compost combined with ammonium nitrate, and in 2015 upon application of a foliar dressing by Azosol also.

In 2016 the Belgorodskaya 48 had a considerable advantage in the yielding capacity as compared with Lantsentnaya in all options of the factor B (fertilizer), in control as well.

The impact of fertilizers on this indicator also depended on the year conditions. In 2014 the yielding capacity of soybean of the variety Belgorodskaya did not depend on the fertilization level whereas the yielding capacity of the variety Lantsentnayagrew significantly upon application of compost fertilizers except for their combined use with Azosol.

In 2015 a similar impact of fertilizers was observed. The difference in the yielding capacity level upon application of compost and in case of Belgorodskaya 48 upon the combined use of compost with ammonium nitrate was within the experimental error, whereas all other options of fertilizers resulted in a considerable growth of the yielding capacity with an upward trend upon application of additional fertilization in plantings of the variety Lantsentnaya.

In 2016 all options of fertilization except for a separate application of mineral fertilizers resulted in a significant growth of the yielding capacity of soybean of the variety Belgorodskaya 48 . The yielding capacity of the variety Lantsentnaya credibly increased only 
in case of an independent application of compost andammonium nitrateand their application with Azosol.

Thus, as a result of our research it was shown that the behavior of varieties belonging to different maturity groups is unstable and largely depends on the weather conditions of a year. The research period included the years of favourable weather conditions (2014-2015), when the early-ripening variety Lantsentnaya had a significant increment in yielding capacity. More severe weather conditions of 2016 revealed the advantages of a soft mid-season variety Belgorodskaya 48. It caused a lack of any significant difference between these varieties for the average of three years. 
Table1. Yielding capacity of soybean varieties depending on fertilizers, tonne/ha

\begin{tabular}{|c|c|c|c|c|c|c|c|c|c|c|c|}
\hline \multirow{3}{*}{$\begin{array}{l}\text { Fertilizer } \\
\text { (factor B) }\end{array}$} & \multicolumn{10}{|c|}{ Variety (factor A) } & \multirow{3}{*}{$\begin{array}{c}\text { An } \\
\text { average of } \\
\text { factorB }\end{array}$} \\
\hline & \multicolumn{5}{|c|}{ Lantsentnaya } & \multicolumn{5}{|c|}{ Belgorodskaya48 } & \\
\hline & 2014 & 2015 & 2016 & $\begin{array}{l}\text { 3-year } \\
\text { average }\end{array}$ & tto control & 2014 & 2015 & 2016 & $\begin{array}{l}\text { 3-year } \\
\text { average }\end{array}$ & $\begin{array}{l}\text { tto } \\
\text { control }\end{array}$ & \\
\hline $\begin{array}{l}\text { Control w/o } \\
\text { fertilizer }\end{array}$ & 2.43 & 3.56 & 1.40 & 2.46 & - & 2.41 & 3.50 & 1.84 & 2.58 & - & 2.52 \\
\hline Compost & 2.90 & 3.68 & 2.06 & 2.88 & 0.42 & 2.64 & 3.54 & 2.41 & 2.86 & 0.28 & 2.87 \\
\hline Compost+ Naa & 3.00 & 3.84 & 1.60 & 2.81 & 0.35 & 2.61 & 3.64 & 2.53 & 2.93 & 0.35 & 2.87 \\
\hline $\begin{array}{l}\text { Compost }+\mathrm{Naa}+ \\
\text { Azosol }\end{array}$ & 3.04 & 4.19 & 1.80 & 3.01 & 0.55 & 2.47 & 3.90 & 2.76 & 3.04 & 0.46 & 3.03 \\
\hline Compost + Azosol & 2.65 & 3.85 & 1.86 & 2.79 & 0.33 & 2.62 & 3.88 & 2.53 & 3.01 & 0.43 & 2.90 \\
\hline Azosol & 2.65 & 3.96 & 1.52 & 2.71 & 0.25 & 2.54 & 3.87 & 2.01 & 2.81 & 0.23 & 2.76 \\
\hline $\mathrm{Naa}+\mathrm{Azosol}$ & 2.54 & 4.01 & 1.98 & 2.84 & 0.38 & 2.50 & 3.77 & 2.43 & 2.90 & 0.32 & 2.87 \\
\hline Naa & 2.62 & 3.84 & 1.92 & 2.79 & 0.33 & 2.58 & 3.82 & 2.19 & 2.86 & 0.28 & 2.83 \\
\hline $\begin{array}{l}\text { An average of } \\
\text { factor } A\end{array}$ & 2.73 & 3.87 & 1.77 & 2.79 & 0.33 & 2.55 & 3.74 & 2.34 & 2.88 & 0.30 & - \\
\hline $\mathrm{HCP}_{05} \mathrm{~A}$ & 0.18 & 0.11 & 0.21 & 0.16 & & - & - & - & & & - \\
\hline $\mathrm{HCP}_{05} \mathrm{~B}$ and $\mathrm{AB}$ & 0.37 & 0.22 & 0.42 & 0.33 & & & & & & & \\
\hline
\end{tabular}


Unstable weather conditions in different years observed in the region under study (southwestern part of the Central Black Earth Region), which largely determine the behaviour of varieties from different maturity groups giving advantages either to the early-ripening or midseason varieties preconditions the necessity for availability of soybean varieties of different maturity in farms. It will allow stabilizing the production of soybean seeds irrespective of the weather factors.

Weather conditions also influence the efficiency of application of different types of fertilizers. Nevertheless, on average for three years a positive increment in the yielding capacity of soybean seeds of the variety Belgorodskaya 48 was observed upon application of two- and three-component manure fertilizers (by $0.35-0.46$ tonnes/ha); as for the variety Lantsentnaya - upon application of all options of fertilizers except for a separate use of a foliar dressing by Azosol (by 0.33-0.55 tonnes/ha). Irrespective of the variety the maximum yielding capacity of soybean seeds was observed upon application of a complete fertilizer "compost + ammonium nitrate + Azosol" $-3.01-3.04$ tonnes/ha, which is 18-22\% larger as compared with control.

\subsection{Soybean Seed Quality}

Apart from significance of the level of yielding capacity of soybean seeds for the producers, important are the indicators of their quality: content of protein and fat which largely determines economic efficiency in the processing industry.

On average for three years of research the studied soybean varieties Lantsentnaya andBelgorodskaya 48 did not have any significant difference with respect to the protein content in seeds which was equal to $36.5-37.5 \%$. The soybean variety Lantsentnaya had a positive advantage by $1.4-1.8 \%$ only in the control option and in two options of fertilizers application: separately with the foliar dressing and combined with the ammonium nitrate (Table2).That is to say compost application for the mid-season variety contributed to leveling of variety differences as compared with a more "protein" early-ripening variety.

At that the same options (compost-based) for seeds of the variety Belgorodskaya 48 considerably increased protein content which grew upon saturation of the fertilization level to $39 \%$. The protein content grew essentially in the soybean seeds of the variety Lantsentnaya as well upon combined application of compost and ammonium nitrate in two- and threecomponent fertilizers, and upon independent application of Azosol.

As for the second quality indicator - fat content - the situation was more explicit implying distinct advantages of the early-ripening variety Lantsentnaya. In all options of fertilization except for "ammonium nitrate" the variety was vastly superior to the mid-season variety Belgorodskaya 48 . The difference in fat content in seeds was $1.4 \%$ for three years on average. 
The research results testify that fat content in soybean seeds practically did not depend on the fertilizers applied. Its content was credibly lower in seeds of both varieties (by 2.2-2.7\%) only upon combined application of compost and ammonium nitrate. It is worth mentioning that specifically these options of fertilizers resulted in the highest protein content in the seeds of varieties and secured the maximum and one of the highest levels of yielding capacity in the varieties under study.

In this case our research proves the results obtained earlier and testifying that under favourable conditions for heavy yield the seeds with higher protein content are gained (Albert et. al., 1976).

At that the assumed dependence is confirmed by high correlation coefficient between the seed quality indicators $-\mathrm{r}=-0.92-0.99$, characterizing the dependence as a negative one, very close and practically functional. 
Table 2. Indicators of Soybean Seed Quality Depending on Fertilization Status on Average for the Years 2014-2016.

\begin{tabular}{|c|c|c|c|c|c|c|c|c|}
\hline \multirow[b]{3}{*}{$\begin{array}{l}\text { Fertilizer } \\
\text { (factor B) }\end{array}$} & \multicolumn{8}{|c|}{ Variety (factor A) } \\
\hline & \multicolumn{4}{|c|}{ Lantsentnaya } & \multicolumn{4}{|c|}{ Belgorodskaya 48} \\
\hline & $\begin{array}{c}\text { Protein } \\
\text { content, \% }\end{array}$ & $\begin{array}{c}\text { Protein } \\
\text { yield, } \\
\text { tonne/ha }\end{array}$ & $\begin{array}{c}\text { Fat content, } \\
\%\end{array}$ & $\begin{array}{l}\text { Fat yield, } \\
\text { tonne/ha }\end{array}$ & $\begin{array}{c}\text { Protein } \\
\text { content, \% }\end{array}$ & $\begin{array}{c}\text { Protein } \\
\text { yield, } \\
\text { tonne/ha }\end{array}$ & $\begin{array}{c}\text { Fat content, } \\
\%\end{array}$ & $\begin{array}{l}\text { Fat yield, } \\
\text { tonne/ha }\end{array}$ \\
\hline Control w/o fertilizer & 35.3 & 0.89 & 23.3 & 0.57 & 33.7 & 0.90 & 22.1 & 0.55 \\
\hline Compost & 37.6 & 1.09 & 22.3 & 0.63 & 36.9 & 1.07 & 20.4 & 0.57 \\
\hline Compost + Naa & 39.1 & 1.12 & 21.1 & 0.58 & 38.8 & 1.14 & 19.4 & 0.56 \\
\hline $\begin{array}{l}\text { Compost }+\mathrm{Naa}+ \\
\text { Azosol }\end{array}$ & 39.2 & 1.20 & 21.2 & 0.62 & 39.0 & 1.19 & 19.4 & 0.58 \\
\hline Compost + Azosol & 37.6 & 1.06 & 21.9 & 0.60 & 36.8 & 1.13 & 20.6 & 0.61 \\
\hline Azosol & 38.1 & 1.05 & 21.7 & 0.58 & 36.3 & 1.05 & 20.7 & 0.56 \\
\hline $\mathrm{Naa}+$ Azosol & 36.0 & 1.04 & 23.1 & 0.65 & 34.6 & 1.03 & 21.7 & 0.61 \\
\hline $\mathrm{Naa}$ & 36.7 & 1.04 & 22.6 & 0.62 & 36.1 & 1.06 & 22.1 & 0.63 \\
\hline An average of factor $B$ & 37.5 & 1.06 & 22.2 & 0.61 & 36.5 & 1.07 & 20.8 & 0.58 \\
\hline $\begin{array}{l}\mathrm{HCP}_{05} \mathrm{~A} \\
\mathrm{HCP}_{05} \mathrm{~B}(\mathrm{AB})\end{array}$ & $\begin{array}{l}1.21 \\
2.42\end{array}$ & - & $\begin{array}{l}0.84 \\
1.68\end{array}$ & - & - & - & - & - \\
\hline
\end{tabular}


According to Shvedov I.V. (2004) the most conservative indicator is an aggregate amount of protein and fat in soybean seeds. In our research this indicator reaches the maximum value at the same two options: upon the combined application of compost and ammonium nitrate in a two- and three-component fertilizer. In case of the variety Belgorodskaya 48 it makes 58.2$58.4 \%$, and in case of the variety Lantsentnaya it makes $60.2-60.4 \%$.

With respect to the protein yield the varieties practically did not differ. This indicator amounted to 1.1 tonne/ha on average for three years. The maximum amount was achieved upon application of a complete three-component fertilizer - 1.2 tonne/ha, which exceeded control by 0.3 tonne/ha. The available advantages of the variety Lantsentnaya with regard to the fat content in seeds affected its harvest from the unit of area as well. It was somewhat larger - by $30 \mathrm{~kg} / \mathrm{ha}$, as compared to the variety Belgorodskaya 48 .

Thus application of compost fertilizers leveled the differences of varieties from different maturity groups with respect to the protein content in soybean seeds which grew upon saturation of the fertilization status by $3.9-5.3 \%$ confirming the opinion that the best conditions for high yield also contribute to the growth of this indicator. As for the fat content the early-ripening variety Lantsentnaya had distinct advantages $-1.4 \%$ higheron average for three years which contributed to the higher yield of oil by $30 \mathrm{~kg} / \mathrm{ha}$.

\subsection{Structural Analysis of Soybean Yield}

The factors that were studied in our experiment had a different impact on the elements of soybean yield structure.

The number of plants on the unit of area is one of the primary indicators of the yield structure. The influence of fertilizers on the density of crop was established in the experiment. All options of fertilizers except for the ammonium nitrate on the plantings of the variety Lantsentnaya considerably increased the number of soybean plants. The greatest excess $(6 \%)$ as compared to control was observed upon application of a three-component fertilizer 481 thous. ea./ha, the same as with the variety Belgorodskaya 48 (5\%) (Table3). Varietal differences did not have any impact on this indicator, only the application of ammonium nitrate caused a positive increment in Belgorodskaya 48.

The number of branches on one plant did not depend either on fertilizers or on varietal features.Only some options of fertilizers gave advantages to one or another variety. For instance, compost gave advantage to Lantsentnaya, and Azosol alone and combined with compost to Belgorodskaya 48. On the contrary the number of beans on one plant was affected by both factors under study. The plants of early-ripening variety had positively more beans as compared with the plants of mid-season variety by 4 ea on average. Fertilizers generally 
increased this indicator. This is with the exception of the ammonium nitrate for the variety Lantsentnaya and Azosol for Belgorodskaya 48.

It is obvious that application of fertilizers due to the positive impact on the number of beans also resulted in the growth of the number of seeds on one plant. The greatest amounts were observed upon application of a complete three-component fertilizer which provided larger increment as compared to control on the plantings of the variety Lantsentnaya - 26.7 ea. $(36 \%)$, than that on the plantings of the variety Belgorodskaya $48-15.3$ ea. $(22 \%)$. On the whole the variety Lantsentnaya had a distinct advantage over Belgorodskaya 48 by 6.68 ea.

The analysis of results with respect to the mass of 1000 seeds did not reveal any impact of variety. Only certain options of fertilizers as for instance "Azosol," "ammonium nitrate + Azosol" gave the advantage to Lantsentnaya, whereas the option "compost + ammonium nitrate + Azosol" on the contrary to Belgorodskaya 48. This option of fertilizer as well as "compost + ammonium nitrate" significantly increased the mass of 1000 seeds in mid-season variety. 
Table 3. Structural Analysis of Soybean Yield Depending on the Fertilization Status for the years 2014-2016 on average.

\begin{tabular}{|c|c|c|c|c|c|c|}
\hline 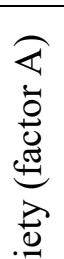 & $\begin{array}{l}\text { Fertilizer } \\
\text { (factor B) }\end{array}$ & $\begin{array}{l}\text { Density of } \\
\text { crop, } \\
\text { thous./ha }\end{array}$ & $\begin{array}{l}\text { Number of } \\
\text { branches on } \\
1 \text { plant, ea. }\end{array}$ & $\begin{array}{l}\text { Number of } \\
\text { beans on } 1 \\
\text { plant, ea. }\end{array}$ & $\begin{array}{l}\text { Number of } \\
\text { seeds on } 1 \\
\text { plant, ea. }\end{array}$ & $\begin{array}{c}\text { Mass } \\
\text { of } \\
1000 \\
\text { seeds }\end{array}$ \\
\hline \multirow{8}{*}{ 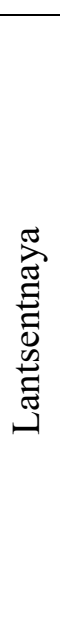 } & Control w/o fertilizer & 453.3 & 2.4 & 38.5 & 74.3 & 137.6 \\
\hline & Compost & 476.7 & 3.0 & 47.9 & 86.1 & 142.2 \\
\hline & Compost $+\mathrm{Naa}$ & 475.0 & 2.9 & 47.7 & 88.8 & 142.5 \\
\hline & $\begin{array}{l}\text { Compost }+\mathrm{Naa}+ \\
\text { Azosol }\end{array}$ & 481.0 & 2.9 & 51.2 & 101.0 & 141.2 \\
\hline & Compost + Azosol & 469.0 & 2.5 & 43.3 & 81.1 & 141.6 \\
\hline & Azosol & 472.0 & 2.6 & 43.9 & 84.9 & 146.2 \\
\hline & $\mathrm{Naa}+$ Azosol & 474.3 & 2.6 & 45.3 & 87.5 & 143.8 \\
\hline & $\mathrm{Naa}$ & 460.0 & 2.6 & 42.3 & 87.6 & 136.9 \\
\hline \multirow{10}{*}{ 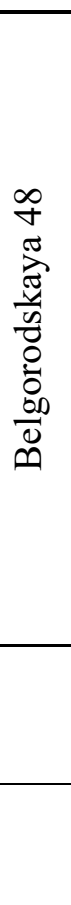 } & Control w/o fertilizer & 459.3 & 2.5 & 35.5 & 69.5 & 130.8 \\
\hline & Compost & 477.7 & 2.6 & 42.6 & 80.1 & 145.3 \\
\hline & Compost + Naa & 472.7 & 2.9 & 41.1 & 81.5 & 149.6 \\
\hline & $\begin{array}{l}\text { Compost }+\mathrm{Naa}+ \\
\text { Azosol }\end{array}$ & 480.7 & 2.9 & 43.1 & 84.8 & 155.3 \\
\hline & Compost + Azosol & 475.7 & 3.0 & 42.7 & 82.6 & 138.1 \\
\hline & Azosol & 467.3 & 3.0 & 40.1 & 77.5 & 136.5 \\
\hline & $\mathrm{Naa}+$ Azosol & 471.3 & 2.8 & 40.7 & 81.9 & 132.5 \\
\hline & $\mathrm{Naa}$ & 475.0 & 2.8 & 41.6 & 80.0 & 138.5 \\
\hline & $\begin{array}{l}\text { An average of factor } \\
\text { B }\end{array}$ & 471.3 & 2.7 & 43.0 & 83.1 & 141.2 \\
\hline & $\begin{array}{l}\mathrm{HCP}_{05} \mathrm{~A} \\
\mathrm{HCP}_{05} \mathrm{~B}(\mathrm{AB})\end{array}$ & $\begin{array}{c}6.74 \\
13.49\end{array}$ & $\begin{array}{l}0.28 \\
0.57\end{array}$ & $\begin{array}{l}2.59 \\
5.19\end{array}$ & $\begin{array}{l}4.88 \\
9.76\end{array}$ & $\begin{array}{l}8.17 \\
16.35\end{array}$ \\
\hline
\end{tabular}

Thus, the elements of the yield structure responded differently to the factors studied in the experiment. If the number of branches on one plant did not depend on fertilizers and varieties, then the number of beans and seeds on one plant was affected by both factors. In this case the 
early-ripening variety and nutrient status intensification had the advantage. The density of crops was positively increased by fertilizers, whereas the mass of 1000 seeds depended on combination of the variety and fertilization option. In general, the values of the yield structure indicators depending on the variety improved with fertilization extent which determined the level of soybean productivity in the experiment.

\subsection{Economic Efficiency of Soybean Cultivation}

The calculation of the economic efficiency of soybean cultivation showed that this is one of the lucrative and economically attractive crops. The level of net profit for the years 2014-2016 on averagechanged from 20.7to26.1thous. rubles/ha (Table4).

The variety of soybean Belgorodskaya 48 proved to be more profitable (by 1.6 thous. rubles/haor $6 \%$ ) for three years on average. The analysis of impact of organic and mineral fertilizers showed that application thereof contributed to the growth of net profit. The highest profit was gained upon application of mineral fertilizers - 24.3-26.1 thous. rubles/ha. The maximum value was observed upon application of Azosol on the variety Belgorodskaya 48. Compost fertilizers proved to be less profitable. In many respects it is associated with considerable expenses for its application. Nevertheless fertilizers with compost due to the positive impact on the yielding capacity were inferior to the mineral ones in profitability only a little reaching 23.5 thous. rubles/ha upon application of a complete three-component fertilizer for the variety Lantsentnaya and 25.5 thous. rubles/haupon application of the option “compost + Azosol" for the variety Belgorodskaya 48.

Table 4 . Economic efficiency of soybean sultivation depending on different fertilization for the years 2014-2016 on average.

\begin{tabular}{|c|c|c|c|c|c|c|c|}
\hline 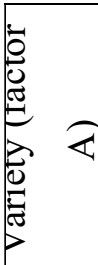 & $\begin{array}{l}\text { Fertilizer } \\
\text { (factor B) }\end{array}$ & $\begin{array}{l}\text { Yielding } \\
\text { capacity, } \\
\text { tonne/ha }\end{array}$ & $\begin{array}{c}\text { Salesrevenue, } \\
\text { rubles/ ha }\end{array}$ & $\begin{array}{c}\text { General } \\
\text { expenses, } \\
\text { rubles/ } \\
\text { ha }\end{array}$ & $\begin{array}{l}\text { Product } \\
\text { cost, } \\
\text { rubles/ } \\
\text { tonne }\end{array}$ & $\begin{array}{c}\text { Net } \\
\text { profitrubles/ } \\
\text { ha }\end{array}$ & $\begin{array}{c}\text { Level of } \\
\text { profitability } \\
\%\end{array}$ \\
\hline \multirow{4}{*}{ 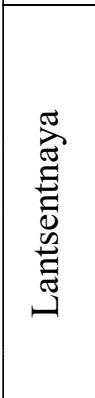 } & $\begin{array}{l}\text { Control w/o } \\
\text { fertilizer }\end{array}$ & 2.46 & 44280 & 23583 & 9586 & 20697 & 88 \\
\hline & Compost & 2.88 & 51840 & 27783 & 9646 & 24057 & 87 \\
\hline & $\begin{array}{l}\text { Compost }+ \\
\text { Naa }\end{array}$ & 2.81 & 50580 & 29783 & 10598 & 20797 & 70 \\
\hline & Compost + & 3.01 & 54180 & 30633 & 10177 & 23547 & 77 \\
\hline
\end{tabular}




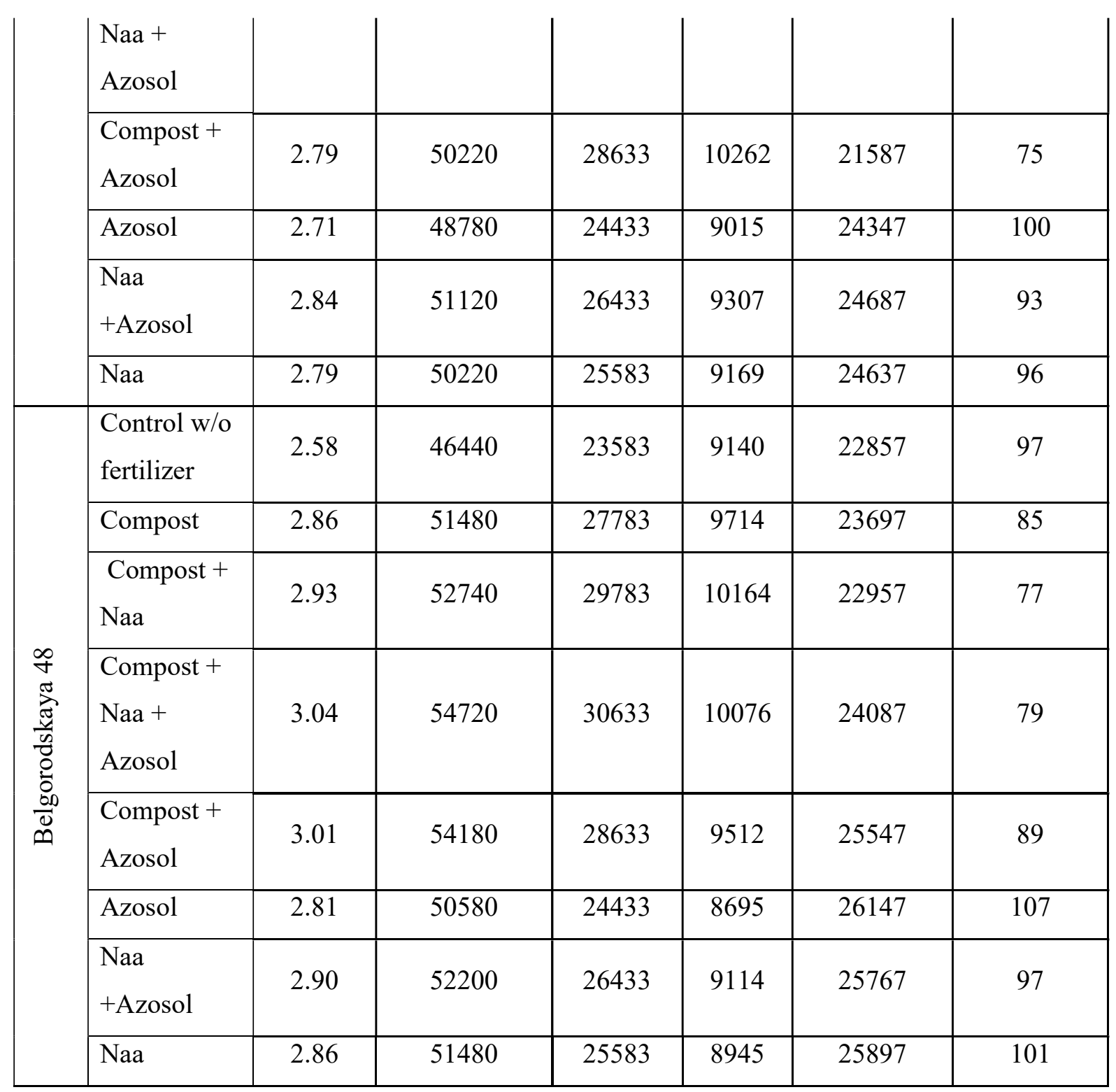

The level of profitability was entirely determined by the returns secured by the fertilizers applied. Compost fertilizers secured significant level of profitability - 70-89\%. Application of ammonium nitrate alone and combined with the foliar dressing enabled to gain $93-101 \%$. The best option proved to be application of Azosol alone - 100-107\%. And even the option without application of fertilizers secured the level of profitability of $88-97 \%$. However taking into account that the obligatory condition of the present-day agricultural production is soil conservation a system approach is required to assess the economic efficiency of different options of fertilizers with due account for subsequent expenses for remediation because of the evident decompensated removal of fertilizer elements upon application of mineral fertilizers specifically Azosol. 
Thus the obtained indicators of economic efficiency characterize soybean as a remunerative crop which can considerably enhance the profitability of the plant industry. In the present-day economic conditions soybean can secure the net profit of 21-26 thous. rubles/ha with the profitability level of $70-107 \%$. The best combination of the factors under study was the application of the foliar dressing Azosol Extra 36 on soybean plantings of the variety Belgorodskaya 48.Despite the considerable difference in expenses the compost fertilizers were inferior to the mineral fertilizers only a little reaching the net profit of 23.5-25.5 thous. rubles/ha.

\section{CONCLUSION}

The results were obtained testifying positive impact of combined application of a manurestraw compost, ammonium nitrate and foliar dressing on the yielding capacity, soybean seeds quality and economic efficiency of cultivation of varieties from different maturity groups.

The research period included the years with favourable weather conditions (2014-2015) when the early-ripening variety Lantsentnaya had a significant increment in yielding capacity - by 0.12-0.18 tonne/haor 3-7\%. More severe hydrothermic conditions of 2016 revealed the advantages of the soft mid-season variety Belgorodskaya 48 (0.57 tonne/haor $32 \%)$. It caused the lack of any significant difference between the varieties for three years on average. It is worth while noting that the varieties realized the potential productivity in 2015 when the average yielding capacity was 3.74-3.87 tonne/ha. The maximum yielding capacity was achieved upon an integrated use of compost, ammonium nitrate and foliar dressing -4.19 tonne/ha for the variety Lantsentnaya and 3.90 tonne/ha for Belgorodskaya 48. The same option of fertilizer proved to be the best for the whole research period providing an increment of $0.35-0.55$ tonne/ha (18-22\%) as compared with the control.

The protein content in soybean seeds did not depend on its variety whereas the fat content was affected by the variety. The early-ripening variety Lanstentnaya had distinct advantages with the fat content higher by $1.4 \%$ on average for three years. The protein content in soybean seeds depended on fertilizers and increased by $3.9-5.3 \%$ upon saturation of the fertilization status proving the opinion that the best conditions for high yields also contribute to the growth of protein content in seeds. The similar trend was observed pertaining to the values of the yield structure indicators which improved upon an increase in the fertilization extent depending on the variety which determined the soybean productivity level in the experiment. The obtained indicators of economic efficiency characterize soybean as a remunerative crop which can considerably enhance the profitability of the plant industry.In the present-day 
economic conditions soybean can secure the net profit of 21-26 thous. rubles/ha with the profitability level of $70-107 \%$. The best combination of the factors under study was the application of the foliar dressing Azosol Extra 36 on soybean plantings of the variety Belgorodskaya 48. Despite a considerable difference in expenses the compost fertilizers were inferior to the mineral fertilizers only a little reaching the net profit of 23.5-25.5 thous. rubles/haat the same time contributing to the conservation of fertility of a typical chernozem.

\section{REFERENCES}

1. Barker D.W., Sawyer J.E.Nitrogen application to soybean at early reproductive development // Agron. J. - 2005. - Vol.97. - P. 615-619.

2. Gan Y., Stulen I., Keulen H. and Kuiper P.J.C. Effect of N fertilizer top-dressing at various reproductive stages on growth, N2 fixation and yield of three soybean (Glycine max (L.) Merr.) genotypes // Field Crops Res. - 2003. - Vol.80. - P. 147-155. http://digitalcommons.unl.edu/agronomyfacpub/133

3. Harper J.E. Soil Symbiotic Nitrogen requirements for optimum Soybean production//Crop Sci.-1974. - №14. - P.255-260.

4. Miyauchi, Y., Isoda A., Li Z., Wang P. Effects of Foliar Application of Humic Substance on Growth and Yield of Soybean in Arid Areas of Xinjiang, China // Japan.J.Crop Sc. - 2012. - Vol.81. - № 3. - P. 259-266.

5. Salvagiotti, F.; Cassman, Kenneth G.; Specht, James E.; Walters, Daniel T.; Weiss, Albert; and Dobermann, Achim R. Nitrogen uptake, fixation and response to fertilizer $\mathrm{N}$ in soybeans: A review // Field Crops Research. - 2008. - Vol.108(1). - P. 1-13.

6. Schmitt M.A., Lamb J.A., Randall G.W., Orf J.H. and Rehm G.W. In-season fertilizer nitrogen applications for soybean in Minnesota // Agron. J. - 2001. - Vol.93. - P. 983-988.

7. Albert V.E., Krasilnikov V.N., Kyuz E.P. et al.Khimicheskiy sostav semyan nekotorykh sortov i ego izmeneniye pod vliyaniyem pogodnykh i pochvenno-klimaticheskikh usloviy [The chemical composition of seeds of some varieties and its change under the influence of weather and soil-climatic conditions] Prikladnaya biokhimiya i mikrobiologiya, 1976,Issue 2,pp. 186-191.

8. Barsukov S.S., Barsukov A.S.Produktivnost soi $\mathrm{v}$ zavisimosti ot deystviya doz organicheskikh i mineralnykh udobreniy v usloviyakh dernovo-podzolistykh supeschanykh pochv [Efficiency of soybean depending on the affect of rates of organic and mineral fertilizers in the conditions of sod-podzol sabulous soils]. Vesnik Mapleuskaga Dzyarzhaunaga universiteta imya A.A. Kulyashova,2005, № 1, pp. 101-106. 
9. Voblasti: 211 tysyach gektarov otdadut pod posev soi v Belgorodskoy oblasti [In the region: 211 thousand hectares will give for crops of soy in the Belgorod region]Available at: http://www.bel.ru/news/region/211-tysyach-gektarov-otdadut-pod-posev-soi-vbelgo.html(Accessed: 10.08.2017)

10. Grudkina T.I., Lavrukhina E.A.Effektivnost proizvodstva soi[Production efficiency of soybean]. Available at:http://www.scienceforum.ru/2013/35/(Accessed: 10.03.2017)

11. Zelenskaya T.I.Rezultaty raboty po importozameshcheniyu soi.Tretia Vserossiyskaya nauchno-prakticheskaya internet-konferentsiya «Klyuchevaya rol soi v obespechenii prodovolstvennoy bezopasnosti Rossii i importozameshchenii produktov pitaniya $v$ sootvetstvii s Ukazom Prizedenta RF ot 6 avgusta 2014 g. № 560 «O primenenii otdelnykh spetsialnykh ekonomicheskikh mer $v$ tselyakh obespecheniya bezopasnosti Rossiyskoy Federatsii». Gosudarstvennoy Programmoy razvitiya selskogo khozyaystva i regulirovaniya rynkov selskokhozyaystvennoy produktsii. syria i prodovolstviya na 2013-2020 gody. Doktrinoy prodovolstvennoy bezopasnosti Rossii». deystvuyushchaya s 20 marta 2015 po 25 marta 2016 goda[Results of work on soy import substitution. The 3d All-Russian scientific and practical conference "The key role of soybean in ensuring food security of Russia and import substitution of food products as per the Decree of the RF President as of August 6, 2014 No. 560 "Concerning application of certain special economic measures to secure safety of the Russian Federation," State Programme for development of agriculture and regulation of agricultural markets, raw materials and food for 2013-2020, the Doctrine of food safety of Russia” valid from March 20, 2015 to March 25, 2016].Available at:http://www.infotechno.ru/ros-soya2014/dok_zelenskaya.php (Accessed: 10.08.2017).

12. Kozlova N.Belgorodskaya oblast - lider po proizvodstvu soi v strane [The Belgorod region - the leader in production of soybean in the country] Available at:

https://www.belpressa.ru/news/news/belgorodskaya-oblast-lider-po-proizvodstvu-soi-vstrane15683/(Accessed: 10.08.2017)

13. Kolesnikov A.Pod Blagoveshchenskom razvernuli programmu soi [The program of soybean was deployed near Blagoveshchensk].Kommersant, 23.05.2014, No. 87, p. 1

14. Kotlyarova O.G., Laktionov P.A.Urozhaynost i simbioticheskaya aktivnost soi v zavisimosti ot sposobov poseva. norm vyseva i urovnya mineralnogo pitaniya [Yielding capacity and symbiotic activity of soybean depending on ways of crops, norms of seeding and level of mineral nutrition]. Dostizheniya nauki i tekhniki APK, 2010,No.5, pp. 44-45.

15. Musorina L.I.Izmenchivost i nasleduyemost belkovosti, maslichnosti i urozhaya semyan soi [Variability and heritability of proten content, oil content and yield of soybean 
seeds]. Tez. dokl. V Vsesoyuzn. obshchestva genetikov i selektsionerov im. N.I. Vavilova, Moscow, 1987, V. 4, P. 2.pp. 35-36.

16. Ob utverzhdenii territorialnoy skhemy obrashcheniya s otkhodami. $v$ tom chisle s tverdymi kommunalnymi otkhodami. na territorii belgorodskoy oblasti. Postanovleniye pravitelstvo belgorodskoy oblasti ot 26 sentyabrya 2016 goda n 350-pp [Concerning the approval of the territorial scheme of waste treatment, including solid municipal waste on the territory of the Belgorod region. The resolution of the government of the Belgorod region as of September 26, 2016 n 350-pp]. Available at: http://belg-gov.ru/doc/35846(Accessed: 15.02.2017)

17. Otraslevaya Programma «Razvitiye proizvodstva i pererabotki soi v Rossiyskoy Federatsii na 2015-2020 gody» (neobkhodimyy obyem finansirovaniya - 195 mlrd.r.). utverzhdena Minselkhozom RF - Protokol № 47 ot 12.11.2014 [Sectorial Programme "Development of Production and Processing of Soybean in the Russian Federation for 20152020" (the necessary amount of financing - 195 billion rubles), approved by the Ministry of Agriculture of the Russian Federation - the Protocol No. 47 of 12.11.2014.Available at: http://www.ros-soya.su/public.aspx?n3(Accessed: 22.07.2017)

18. Perspektivnaya resursosberegayushchaya tekhnologiya proizvodstva soi: Metod. rekomendatsii [Perspective resource-saving production technology of soybean: Method. Recommendations]. Moscow, FGNU «Rosinformagrotekh» Publ., 2008. 56 p. 19. Proizvodstvo soyevykh bobov v Rossii po regionam. reyting 2016 07.11.2016g. Ekspertno-analiticheskiy tsentr agrobiznesa "AB-Tsentr" [Production of soybeans in Russia region-wise, the rating of 2016. 07.11.2016. Expert analytical center of agrobusiness "ABcenter"]. Available at: http://ab-centre.ru/news/proizvodstvo-soevyh-bobov-v-rossii-poregionam-reyting-2016(Accessed: 1.08.2017)

20. Soyevaya revolyutsiya $v$ Rossii [Soybean revolution in Russia]Available at: http://agroobzor.ru/rast/a-114.html (Accessed: 11.08.2017)

21. Titova V.I., Dabakhova E.V., Dabakhov M.V. Rekomendatsii po otsenke ekologicheskogo sostoyaniya pochv kak komponenta okruzhayushchey sredy

[Recommendations on the assessment of an ecological condition of soils as environmental component]. NizhnyNovgorod, VVAGS Publ., 2004. 68 p.

22. Fedotov V.A., Kadyrov S.V., Shchedrina D.I. Agrotekhnologii polevykh kultur v Tsentralnom Chernozemye [Agrotechnologies of field cultures in the Central Black Earth Region]. Voronezh, Istoki Publ., 2011. 260 p. 
23. Fomin I.S. [Issues of modern agriculture in the Central Black Earth Region]. Materialy nauch.-prakt. konf[Proceedings of the scientific and practical conference]. Kursk, 2003. pp. 102-103.

24. Likhachev A.N. Effektivnost udobreniy $i$ kaltsiysoderzhashchikh soyedineniy pri razlichnykh sposobakh vozdelyvaniya soi na chernozeme tipichnom Lesostepi.Avtoref. Dis. na soisk. uch. step. kand. s. $-k h$. nauk [Efficiency of fertilizers and calcium compounds at various methods of soybean cultivation on typical chernozem of the forest-steppe. PhDthesisinagriculturalscience], Курск, 2002. 18 p.

25. Tsaritsa poley: pochemu krupneyshiye agrokholdingi Rossii investiruyut v soyu (RBK). Novosti APK 18.11.2015. Agrovestnik [Tsarina of fields: why do major agroholdings of Russia invest in soybean (RBC) AIC news of 18.11.2015. Agrovestnik].Available at:https://agrovesti.net/novosti_apk/tsaritsa_poley_pochemu_krupneyshie_agrocholdingi_ross ii investiruiut_v_soiu rbk.html (Accessed: 16.02.2016)

26. ShamrayM. TOP 10 stran proizvoditeley soi v mire. 15 maya 2015 [Top 10 soybean producer countries worldwide.мая15, 2015].Available at: http://latifundist.com/rating/top-10stran-proizvoditelej-soi-v-mire (Accessed: 1.02.2017)

27. Shvedov I.V. Svyaz produktivnosti soi s biokhimicheskim sostavom semyan [Connection of soybean productivity with the biochemical composition of seeds].Nauchnotekhnicheskiy byulleten VNII maslichnykh kultur, 2004, No. 1 (130),pp. 46-54.

\section{How to cite this article:}

Kotlyarova E G, Gritsin V G. Productivity and economic efficiency of soybean varieties cultivation upon application of organic and mineral fertilizers. J. Fundam. Appl. Sci., 2017, 9(2S), 1582-1602. 